Radosław Grzybek

\title{
IDENTIFICATION AND ANALYSIS OF MINING AREAS SUBSIDENCE WITH USING INSAR TECHNIQUE BASED ON SENTINEL-1 SAR IMAGERY
}

\author{
AGH University of Science and Technology in Krakow, \\ Faculty of Mining Surveying and Environmental Engineering \\ grzybek.radoslaw@gmail.com
}

Keywords: radar interferometry, mining industry, SAR imagery, coherence

\begin{abstract}
The repeat pass interferometric synthetic aperture radar (InSAR) technique is becoming increasingly common in monitoring Earth's surface and its deformation. It uses at least two radar images of the same area, registered in temporal interval. As a result, the raster of vertical changes (interferogram) is generated. Specifically, it allows to interpret and calculate the value of subsidence in mining areas. A north-west part of Upper Silesian Coal Basin (USCB) in Poland was chosen as the area of interest. Together with interferogram, the coherence image is calculated. That provided to create a mean coherence maps for chosen mining areas in USCB. It allowed to verify in which of them the monitoring with InSAR techniques may be effective.
\end{abstract}

\section{IDENTYFIKACJA I ANALIZA ZMIAN POWIERZCHNI TERENÓW GÓRNICZYCH Z WYKORZYSTANIEM INSAR NA BAZIE ZOBRAZOWAŃ SENTINEL-1}

Slowa kluczowe: interferometria radarowa, górnictwo, zobrazowania SAR, koherencja

\section{Abstrakt}

Metoda radarowej interferometrii powtórnego przelotu staje się coraz bardziej popularna w monitoringu powierzchni Ziemi i jej deformacji. Wykorzystuje ona co najmniej 2 obrazy radarowe zarejestrowane dla tego samego obszaru, w pewnym odstępie czasu. W wyniku zastosowania tej metody wygenerowany zostaje raster pionowych zmian terenu (interferogram). W szczególności umożliwia on interpretację oraz obliczenie wartości obniżeń w rejonie terenów górniczych. Jako obszar badań wybrano północno-zachodnią część Górnośląskiego Okręgu Przemysłowego w Polsce. Razem z interferogramem obliczony zostaje obraz koherencji. Dla każdego z wybranych terenów górniczych stworzono mapę uśrednionej koherencji. Pozwoliło to ocenić, na których terenach górniczych monitoring z wykorzystaniem metody InSAR może być efektywny.

\section{INTRODUCTION}

Underground coal exploitation in the Upper Silesian Coal Basin (USCB) has affected significant and often irreversible changes in the natural environment (Cabała J., et al., 2004). Terrain movements causes heave damages of buidings. Hence, mining areas are continuingly monitored, however, forecasting seismic events is still very difficult.
A remote sensing has a great influence in more and more fields of science and engineering. The InSAR technique is one of the most modern and high-tech approach of this. With using this method, deformation's values of few millimetres can be detected from the spaceborne. The usefulness of radar interferometry in analyzing the terrain movements above underground exploitation has been proved in many studies since 1990s (Perski Z., 1998, Ketelaar G., 2008). 
From 2014 European Space Agency (ESA) is developing family of missions called Sentinels for the operational needs of the Copernicus programme. These missions carry a range of remote sensing data, specifically the radar imagery from first mission of this enterprise - Sentinel-1. Sentinel-1 mission contains two satellites, which registers in day and night performing $\mathrm{C}$-band synthetic aperture radar imaging. It provides to acquiring radar data regardless of the weather. What is significant, these data are free of charge.

In this study the usefulness of InSAR technique with using SAR imagery from Sentinel-1 mission will be presented on four chosen mining areas.

\section{THE AREA OF RESEARCH}

The Upper Silesian Coal Basin is the biggest active area of black coal exploitation in Europe. Moreover, it is characterised by a complicated geological structure. It is located in the south of Poland and its area amounts to 5400 square kilometres. The subsidence terrain is being monitored unceasingly especially with land surveying works.

Land surveying works in mining areas can be divided into three kinds of measurements: levelling (only height coordinate is measured), measurements of distance on survey lines and GPS measurements (X, Y, Z are obtained). Usually, measuring the survey lines is performed once a year or every 6 months. More frequent measurements would have been very expensive. In survey lines there is a need to stabilize even hundreds of benchmarks.

The aim of this study is proving that in some areas in USCB region, the monitoring of surface's deformation and interpreting subsidence areas with using radar interferometry can be possible and effective. Levelling is expensive, thus cannot be performed very frequently. Nevertheless, in some cases, levelling measurements can be efficiently replaced with InSAR technique. Moreover, correlation between value of coherence and land use is analyzed.

\section{METHODOLOGY}

\subsection{The technique of measurement}

SAR interferometry is a remote sensing technique, that uses the phase values of two (or more) SAR images, by subtracting the phase value of one image (master image) from phase value of other images (slave images) (Perski, Z., 2009). Previous studies have proved, that InSAR technique may be used both in regions with dynamic movements over the black coal exploitation and also with slower processes, e.g. over salt mines (Mirek K., 2009). Hence, this method brings plenty of application capabilities and possibilities of scientific studies.

The significant products of this study are the maps of mean coherence for each of the selected mining areas. Coherence is a measure of correlation between a SAR images pair (https://earth.esa.int). Coherence can serve as a measure of the quality of an interferogram. In areas with high coherence values, the interferometric phase shifts can be interpreted efficiently. However, in areas with very low level of coherence, this interpretation may be even impossible.

There are some major aspects influencing on its value, which are directly depended on noise of interferometric phase, e.g.:

- local slope,

- land use and land cover of registered area,

- temporal base between the passes of satellite (the longer it is, the lower coherence may be achieved),

- the perpendicular baseline (the distance between two locations of satellite in space during both registering; the shorter, the better),

- processing errors.

The lowest possible value of coherence is 0 (lack of coherence) and the highest is 1 (perfect coherence).

\subsection{The algorithm of procedures}

The compiling of mean coherence maps demanded a sequence of procedures. After obtaining SAR imagery and creating interferograms, subsidence areas were identified in all interferograms. For each of these areas, the visual rating of quality was performed by assigning it to three classes. Also, the mean value of coherence was calculated for each subsidence area separately. After tabulating all these values in a compact collation, two thresholds of coherence values were determined by rating of quality. This step allowed to reclassify the maps of mean coherence.

Afterwards, coherence imagery were compiled into maps of mean coherence. Firstly, each coherence image was processed with median filter. Then, all these images were summed and divided by the amount of analyzed images. Furthermore, the mean coherence image 
was reclassified to three values - 1, 2, 3. Respectively, these classes were assigned to divisions defined in the classification step.

Another part of this thesis are analyses of obtained products. In the first step, the InSAR technique utility for chosen area of interest was described. Then, the cause of variety of results was analyzed by examining land use and land cover.

In the end, the generalization of achieved reclassified maps of mean coherence was performed.

\section{THE RESEARCH}

For the research, four mining areas located in Upper Silesian Coal Basin in Poland were chosen: Sośnica III, Bielszowice III, Stara Ligota I and Murcki I. These mining areas are included in a major area of interest. Some interferograms were obtained from radar data registered from different orbits. Hence, some of interferograms have a different shape, so a common area of interest was supposed to be defined (Figure 1).

The maps of mining areas are the first type of data used in this study. This data are available via MIDAS system, which delivers products in Web Map Service (WMS). Thus, it was supposed to be digitalized in order to make further analyses. MIDAS is provided by Polish National Research Institute. For each of four se- lected mining areas the same procedure was performed in order to create a map of mean coherence. The second and major source data used were 20 SAR imagery registered by Sentinel-1 mission's satellites which were launched by European Space Agency (ESA). The first satellite (Sentinel-1A) was launched on $3^{\text {rd }}$ of April 2014 and the second one (Sentinel-1B) on $22^{\text {nd }}$ of April 2016. Creating a constellation have resulted in shortening a revisit time twice - from 12 to 6 days. This is a big advantage and huge improving in comparison with ERS-1 and ERS-2 missions, in which repeat interval amounts to 35 days. It gives an opportunity to make various analyses with much bigger amount of radar imagery, in comparison with ERS missions 20 years ago (Perski, et al., 2002). Moreover, the temporal base has a great influence on coherence quality. It may be assumed, that the shorter temporal base is, the higher level of coherence can be expected. Thus, in some researches in this field with using ERS data, only a little percentage of acquired radar imagery could be used for interpreting generated interferograms (Krawczyk A., et al., 2007). Nevertheless, registered imagery from both Sentinel-1 instruments are available from $27^{\text {th }}$ of September 2016. Hence, the period of this research is contained in the period of registering data by both satellites. Furthermore, due to Copernicus agenda all imagery are available for the public free of charge.

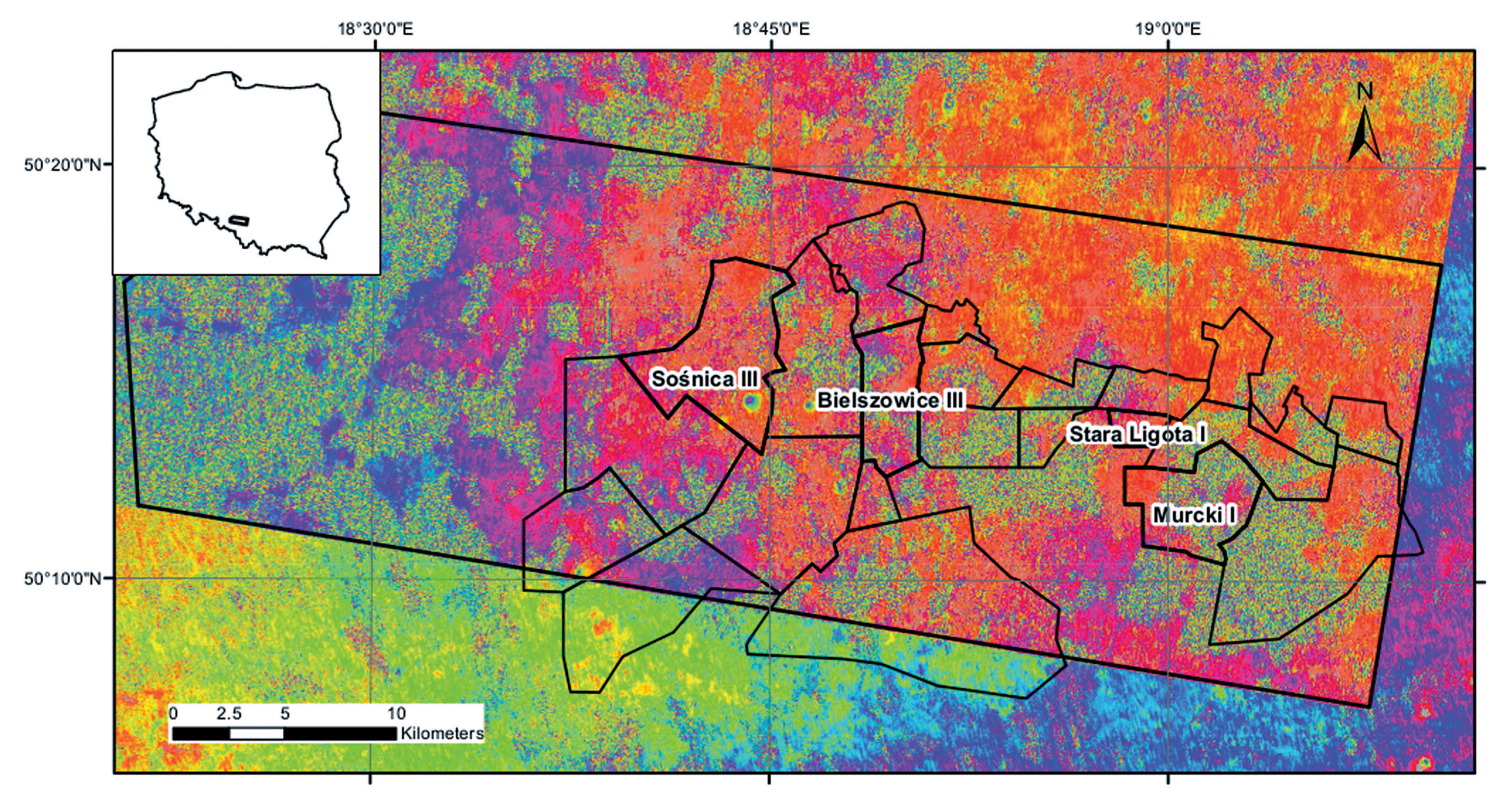

Fig. 1 Area of interest with selected four mining areas with interferograms in the background Rys. 1. Obszar badań wraz z czterema wybranymi terenami górniczymi z interferogramami w tle 
Table 1. Interferogram collation

Tabela 1. Zestawienie interferogramów

\begin{tabular}{|c|c|c|c|}
\hline ID & Interferogram period & Temporal base [days] & Number of subsidence areas \\
\hline int1 & $20161103-20161109$ & 6 & 4 \\
\hline int2 & $20161111-20161117$ & 6 & 6 \\
\hline int3 & $20161117-20161123$ & 6 & 3 \\
\hline int4 & $20161123-20161205$ & 12 & 4 \\
\hline int5 & $20161205-20161217$ & 6 & 2 \\
\hline int6 & $20161217-20161223$ & 6 & 4 \\
\hline int7 & $20170119-20170125$ & 6 & 9 \\
\hline int8 & $20170126-20170201$ & 6 & 7 \\
\hline int9 & $20170225-20170303$ & 6 & 7 \\
\hline int10 & $20170303-20170309$ & 12 & 4 \\
\hline int1 & $20170309-20170321$ & 6 & 5 \\
\hline int12 & $20170321-20170327$ & 6 & 5 \\
\hline int13 & $20170327-20170402$ & 6 & 2 \\
\hline int14 & $20170404-20170410$ & 12 & \\
\hline
\end{tabular}

A sensing time of the first downloaded image was 03.11.2016 and 10.04.2017 of the last one. Thus, time frame of this study included 158 days. From these radar data 14 interferograms with temporal base of 6 or 12 days were computed. Simultaneously, the same amount of coherence images were obtained, respectively. The collation of analyzed interferograms (and coherence imagery) is shown in Table 1. By summing up temporal

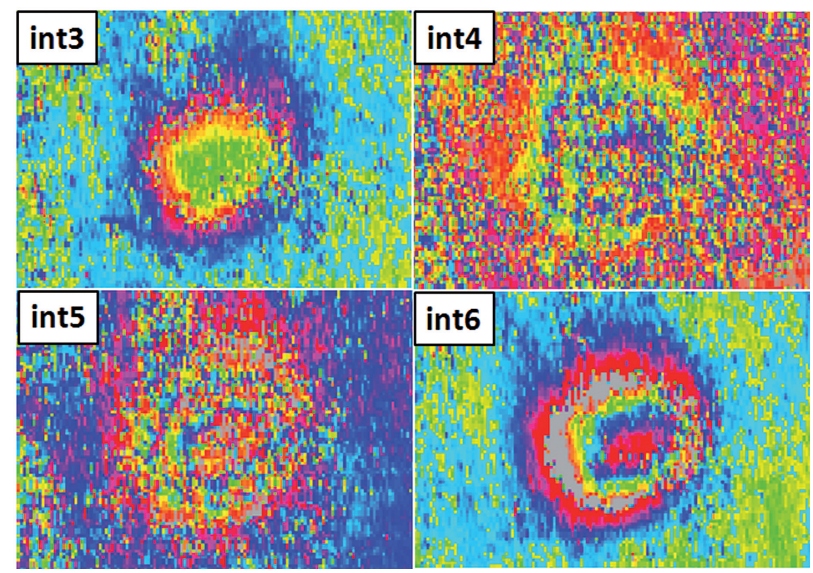

Fig. 2. Subsidence area in Bielszowice III mining area with temporal decorrelation

Rys. 2. Niecka obniżeniowa na terenie górniczym Bielszowice III z czasową dekorelacją bases of all interferograms, it can be deduced, that 102 days were observed, during which 67 subsidence areas were identified. Thus, taking into account time frame, observation's percentage can be estimated as $65 \%$.

In the first step, subsidence areas were identified in all interferograms. In practice (excluding an impact of local slopes, because of the analyzed terrain's approximate flatness), there are two main reasons of noising

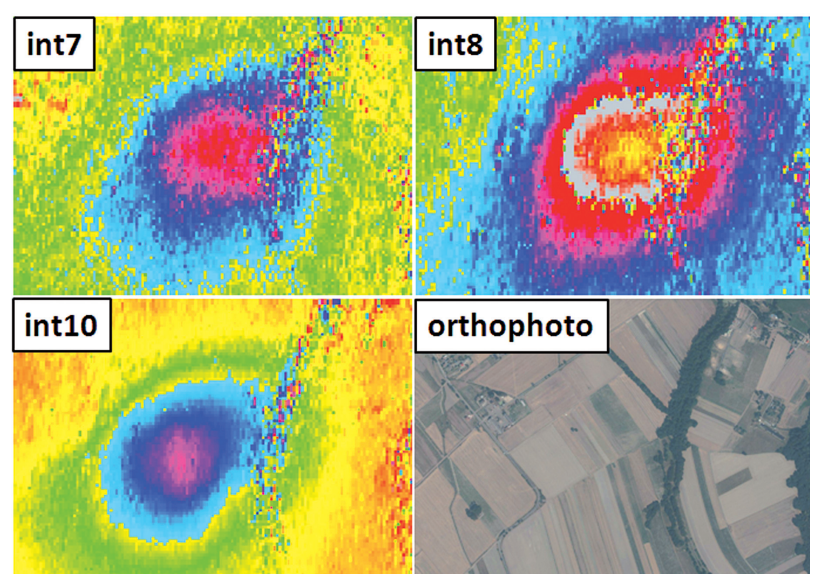

Fig. 3. Subsidence area in Ornontowice I mining area with decoherence caused by land cover

Rys. 3. Niecka obniżeniowa na terenie górniczym Ornontowice I z dekoherencją spowodowaną pokryciem terenu 
Table 2. Collation of subsidence areas in mining areas in AOI

Tabela 2. Zestawienie niecek obniżeniowych na terenach górniczych w AOI

\begin{tabular}{|l|c|c|c|c|c|c|c|c|c|c|c|c|c|c|c|}
\hline $\begin{array}{c}\text { Name of mining } \\
\text { area }\end{array}$ & int1 & int2 & int3 & int4 & int5 & int6 & int7 & int8 & int9 & int 10 & int $\mathbf{1 1}$ & int 12 & int 13 & int 14 & sum \\
\hline Knurów & & 1 & 1 & 1 & 1 & 1 & 1 & 1 & & 2 & 2 & 1 & & 1 & $\mathbf{1 3}$ \\
\hline Sośnica III & 1 & 1 & 1 & 1 & & & & & & 1 & 1 & 1 & 1 & 1 & $\mathbf{9}$ \\
\hline Ornontowice I & & 1 & 1 & 1 & 1 & 1 & 1 & 1 & 1 & 1 & 1 & 1 & 1 & 1 & $\mathbf{1 3}$ \\
\hline Makoszowy II & 1 & 1 & 1 & & 1 & 1 & & & & & & & & & $\mathbf{5}$ \\
\hline Bielszowice III & 1 & 1 & 1 & & 1 & 1 & & 1 & & & & & & & $\mathbf{6}$ \\
\hline Wirek II & & & & & & & & & & & 1 & & 1 & 1 & $\mathbf{3}$ \\
\hline Halemba I & 1 & 1 & & & & 1 & & 1 & & & 1 & & & & $\mathbf{5}$ \\
\hline $\begin{array}{l}\text { Ruda Śląska } \\
\text { Radoszowy }\end{array}$ & & & & & & & & 1 & & & & & & & $\mathbf{1}$ \\
\hline Giszowiec I & & & & & & & 1 & 2 & & & & & & & $\mathbf{3}$ \\
\hline
\end{tabular}

in radar imagery. The first one is atmospheric influence, mostly connected with air and soil moisture changes. Specifically, if in master image registered soil is very dry, even small changes in contents of water in slave image will result in high decorrelation which induces low coherence (Yin Q., et al., 2017). This situation can be observed in interferograms named int 4 and int 5 for example in subsidence area located in Bielszowice III mining area. In the previous and further interferograms this subsidence area is easy to detect, but in int 4 and int5 the noise makes an identification difficult (Figure 2). This is a result of a phenomena called temporal decorrelation which is related with changes in the electromagnetic properties (e.g. variable water vapour distribution) (Hanssen R., et al., 2005).

The second reason of decoherence is land use and land cover. It can be observed easily even without any background information about specified terrain. In some subsidence areas it can be noticed, that some pieces of interferograms are noised steadily in time. Usually it means, that these areas are covered with land, in which radar signal backscattering is not efficient (e.g. forest, water bodies). An example of this situation is shown in Figure 3.

In this article the second reason, connected with land use and land cover is mainly analyzed.

The collation of identified subsidence areas in mining areas inside (but not intersecting) the area of interest (AOI) was depicted for each interferogram separately (Table 2). The mining areas with subsidence regions amount equal to 0 were not included in this collation (these mining areas are: Ornontowice II, Zabrze I, Halemba II, Ruda Śląska - Panewniki II, Katowice Brynów, Stara Ligota I, Bogucice, Murcki I, Janów, Mysłowice).

\subsection{Classification}

The Upper Silesian Coal Basin is a very dynamic area. The vertical movement nearby subsidence areas can be up to 5 millimetres per day (Cabała J., et al., 2004). Hence, if coherence is high enough, these areas can be noticed in the interferogram very easily (Table 3 ). It is clearly visible, that the brighter the image of coherence is, the higher coherence value and better quality of interferogram is compiled.

The ranges of subsidence areas were assumed as a reference data in the classification process. Some of the subsidence areas visible in obtained interferograms were arranged in the Table 4. Moreover, each of them were rated according to its quality. Thus, three classes were assigned to each subsidence area:

- class 1 - subsidence areas barely visible, difficult to identify;

- class 2 - areas well visible but with non-smooth, sharp fringe patterns which allows to draw in subsidence isolines only with its interpolating;

- class 3 - areas well visible with smooth fringe patterns which allows to draw in subsidence isolines and computing the volume. 
Table 3. Comparison between interferogram and coherence image

Tabela 3. Porównanie interferogramów z obrazami koherencji

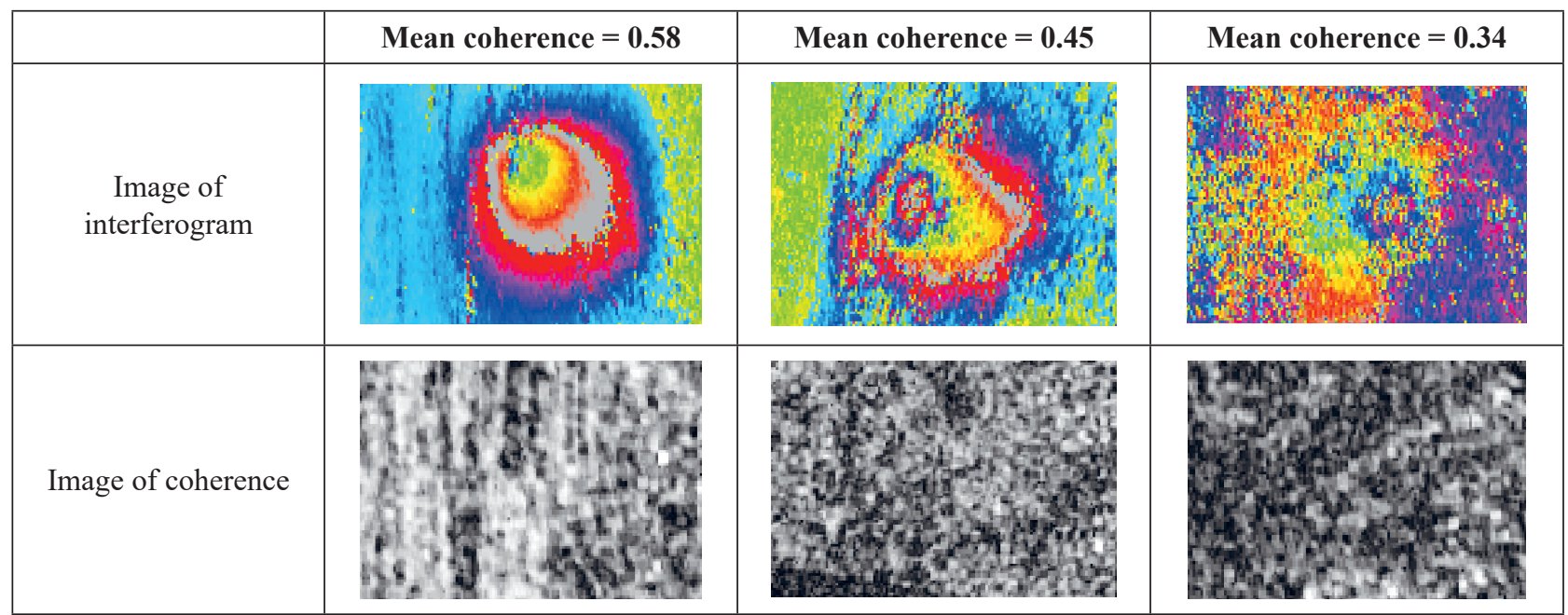

This procedure was based on visible rating only. To choose which values should be assigned to these classes, the boundaries of ranges of all subsidence areas were digitalized. Afterwards, each vector was intersected with corresponding coherence image. Eventually, the mean coherence values for each area was calculated and tabulated in Table 4. For classifying, the table was sorted according to values of classes. The ID is a defined number of subsidence area, e.g. 2.4 is the fourth subsidence area in interferogram named int 2 .

Hence, three divisions of pixel value were set down: $0-0.40$ (lack of coherence); $0.40-0.54$ (medium coher-

Table 4. Coherence of subsidence areas classification (14 examples from 67 subsidence areas)

Tabela 4. Klasyfikacja koherencji niecek obniżeniowych (14 przykładów z 67 niecek)

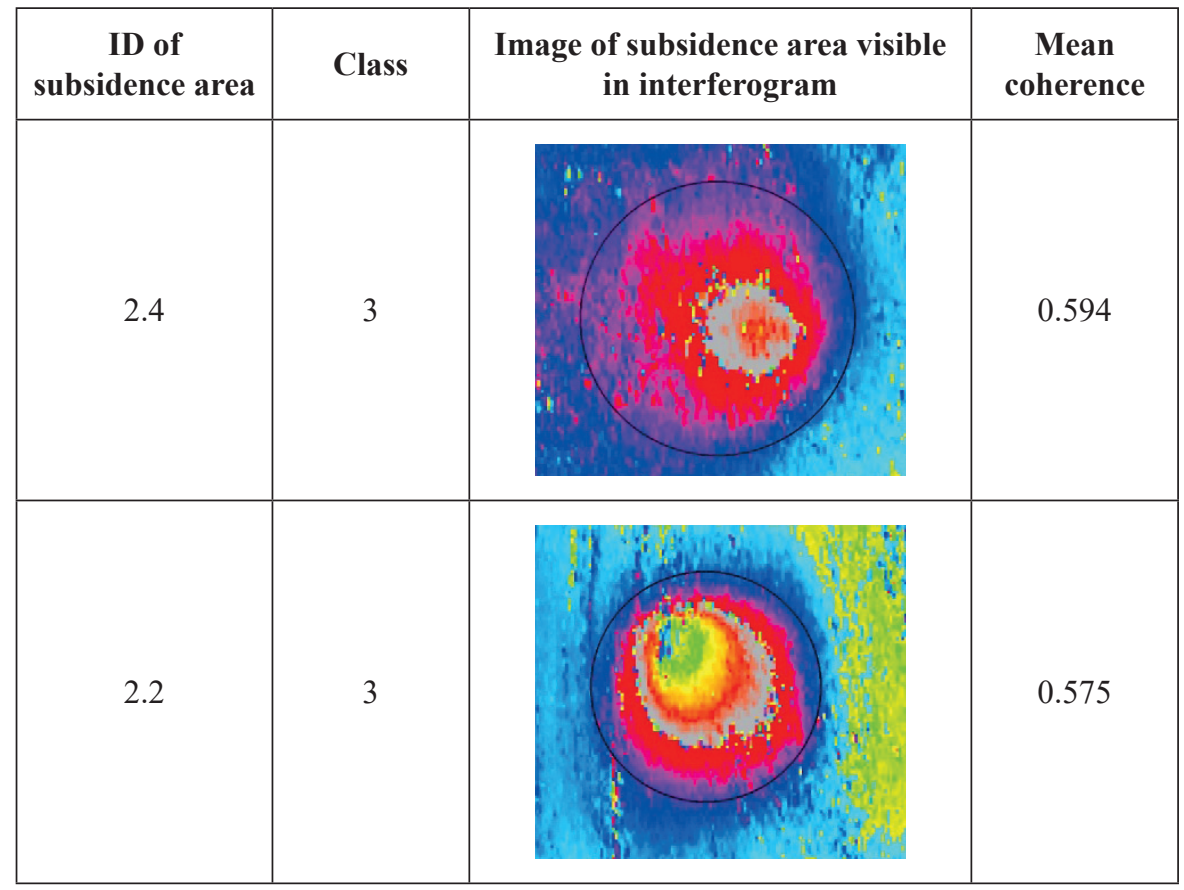


Table 4. Cont.

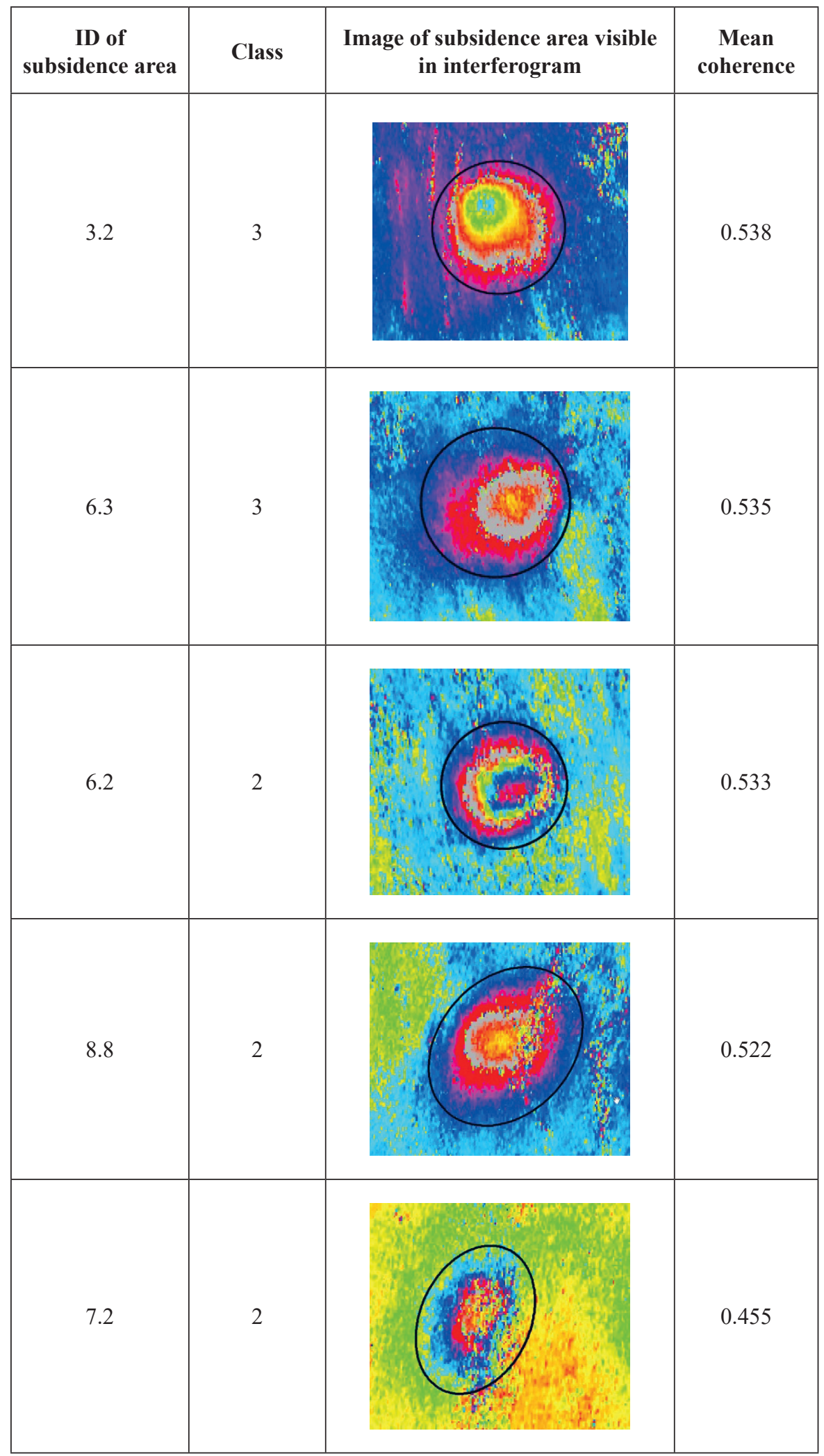


Table 4. Cont.

\begin{tabular}{|c|c|c|c|}
\hline $\begin{array}{c}\text { ID of } \\
\text { subsidence area }\end{array}$ & Class & $\begin{array}{c}\text { Image of subsidence area visible } \\
\text { in interferogram }\end{array}$ & $\begin{array}{c}\text { Mean } \\
\text { coherence }\end{array}$ \\
\hline 8.9 & 2 & & 0.449 \\
\hline 7.3 & 2 & & 0.408 \\
\hline 5.1 & 2 & & 0.405 \\
\hline 5.5 & 1 & & 0.387 \\
\hline 4.1 & 1 & & 0.385 \\
\hline
\end{tabular}


Table 4. Cont.

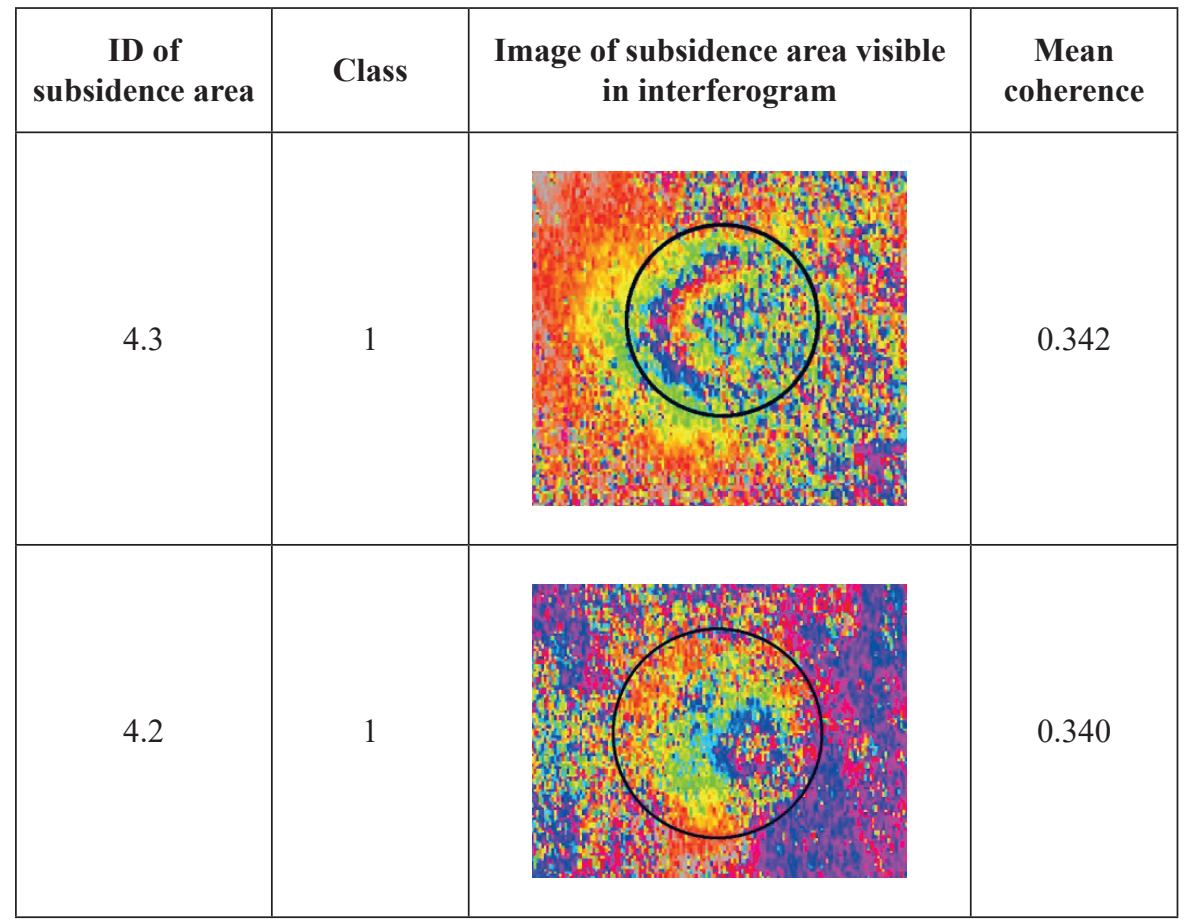

ence enough to detect subsidence area, although not without a noise); 0.54-1 (high coherence). The values of new classes were assigned to numbers $1,2,3$, respectively. This classification was necessary in further procedures, after creating maps of mean coherence.

\subsection{Preparing the data}

To analyze coherence imagery there was a need to process it into more simply form. To make it possible ArcGIS software by ESRI was used. Firstly, coherence imagery were clipped into chosen four mining areas separately. Afterwards, it was transformed to 8-bit values only (originally 32-bit) for making statistics calculating executable. Coherence image has a high level of noise which is revealing by a large number of single pixels with far too different value than pixels in close neighbourhood. Thus, the classification would not be efficient. To deal with that problem it was decided to process the imagery with median filter.

Median filter is very effective at removing 'salt and pepper’ type noise with preserving edges (Gonzalez R. C., Woods R. E., 2008). The aim of filtering an image is to calculate median value within a neighbourhood defined by a square matrix called 'window'. This process is computed for whole image pixel by pixel. For this research the matrix with size of 5 by 5 pixels was defined. This is sufficient window to remove most of the noise, especially for some pixels which have suddenly very high value of coherence in the area where a coherence is usually close to zero (e.g. forest, water bodies). Each of described steps was done for all coherence images for each mining area and also for whole area of interest.

The next step of preparing data for analysis was summing all 14 filtered coherence imagery and then dividing it by the amount of analyzed images. Hence, the mean coherence image was calculated (Figure 4). Reclassified maps are presented in Figure 5.

\subsection{Analysis of selected mining areas}

The final reclassified mean coherence raster can be useful to many researches. The need of defining which mining areas in USCB may be monitored using radar interferometry was remarked. Taking into consideration land use and land cover, only some mining areas in USCB can be researched efficiently with using these measurements. To confirm which of chosen four mining 

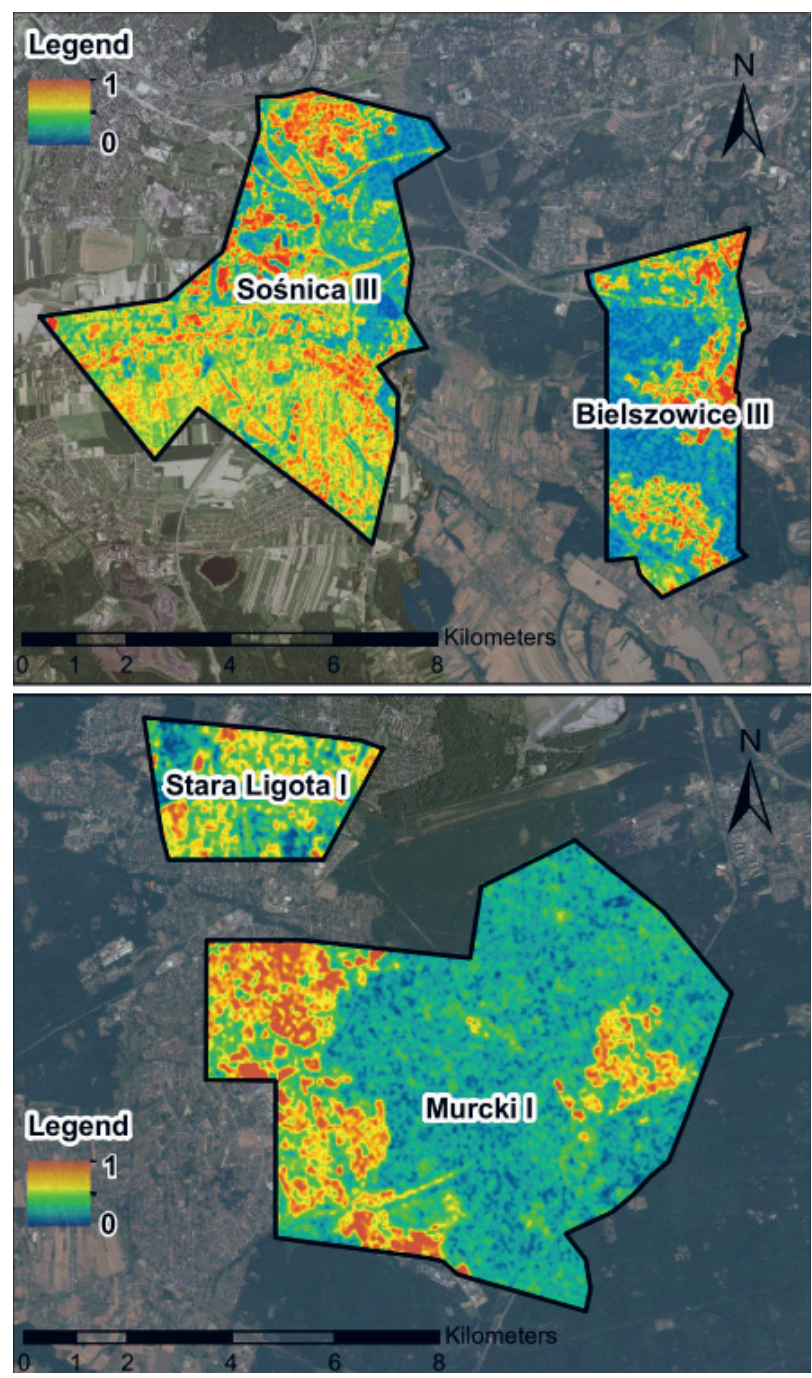

Fig. 4. Mean coherence images for selected mining areas Rys. 4. Obrazy uśrednionej koherencji dla wybranych terenów górniczych
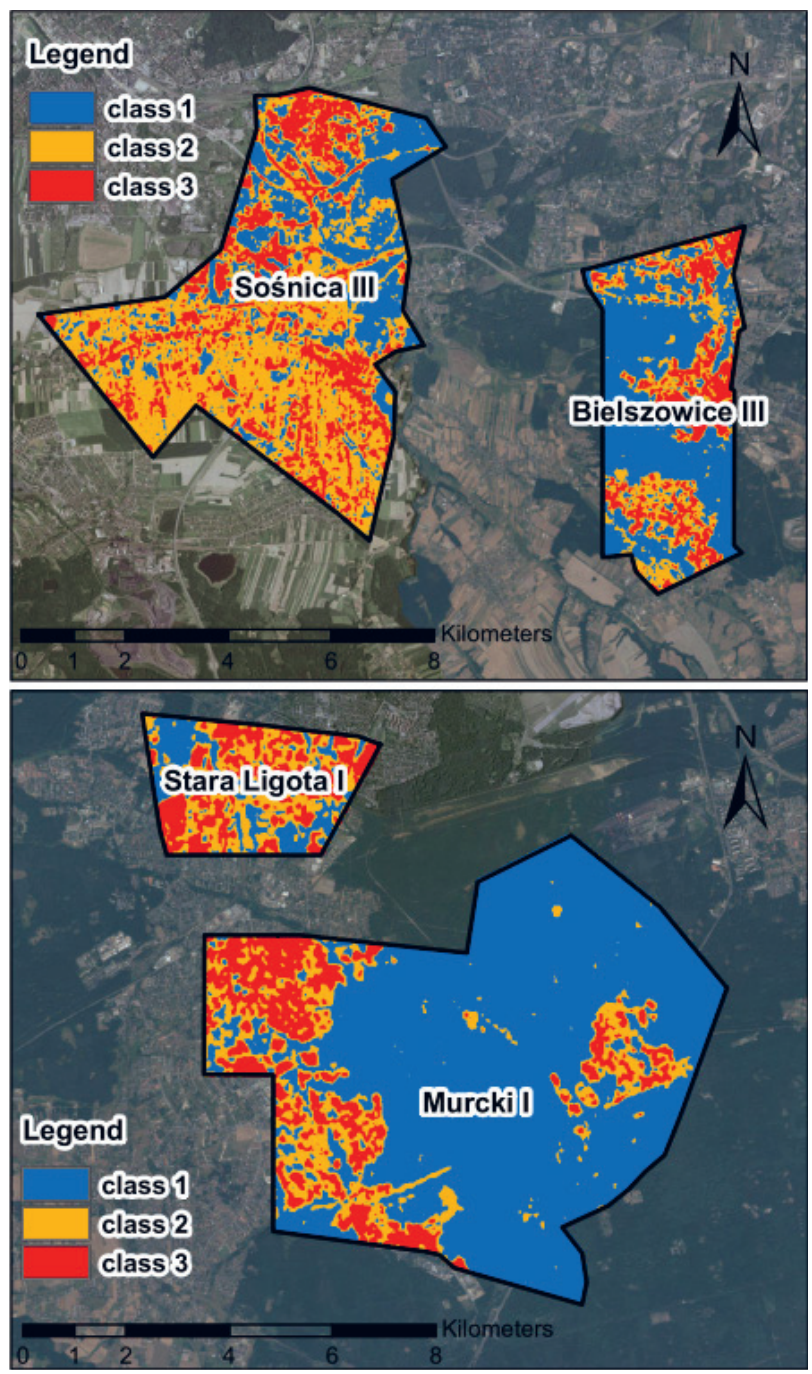

Fig. 5. Reclassified mean coherence images for selected mining areas

Rys. 5. Zreklasyfikowane obrazy uśrednionej koherencji dla wybranych terenów górniczych

Table 5. Results of calculated coherence classes' areas for each mining area and whole area of interest

Tabela 5. Wyniki obliczonych powierzchni klas koherencji dla terenów górniczych i całego obszaru badań

\begin{tabular}{|l|c|c|c|}
\hline \multicolumn{1}{|c|}{ Mining area } & $\begin{array}{c}\text { Low coherence } \\
\text { (class 1) [ha] }\end{array}$ & $\begin{array}{c}\text { Medium coherence } \\
\text { (class 2) [ha] }\end{array}$ & $\begin{array}{c}\text { High coherence } \\
\text { (class 3) [ha] }\end{array}$ \\
\hline Stara Ligota I & 89.3 & 146.7 & 126.0 \\
\hline Sośnica III & 807.1 & 1660.3 & 773.8 \\
\hline Bielszowice III & 927.6 & 414.5 & 304.1 \\
\hline Murcki I & 1558.7 & 293.7 & 250.7 \\
\hline Area of Interest & 61163.7 & 32221.0 & 14873.5 \\
\hline
\end{tabular}


areas are appropriate for further studying, the areas of classes were calculated for each mining area separately and also for whole area of interest. A table with results in hectares is shown in Table 5 .

Calculated areas in hectares were compiled into percentage values and sorted according to highest contribution of class 3 . The bar graph of its values based on Table 5 is presented in Figure 6.

Analyzing this chart it can be deduced, that Stara Ligota I and Sośnica III mining areas have a potential to be studied effectively with InSAR technique. Less than $25 \%$ of these areas is assigned to class 1 , which means, that in over three-quarters of these regions subsidence areas could be identifying and analyzing. Moreover, in Stara Ligota I 35\% belongs to class 3, so usually a high coherence is computed in this area. The opposite situation is in Murcki I, where only one-quarter of this mining area can be examined with InSAR technique. Whereas Bielszowice mining area is very representative for whole area of interest in this statistic.

To find out, what is the reason of these differences between coherence in these mining areas, the land use and land cover were examined. To do that, open sourced data from Urban Atlas were used (https://www. eea.europa.eu/data-and-maps/data/urban-atlas). The Urban Atlas service offers a high resolution land use map of urban areas. This product is adapted to European needs and contains information that can be derived mainly from Earth Observation data with support by other reference data, such as COTS navigation data and topographic maps. The GIS data can be downloaded for Large Urban Zones with more than 100.000 inhabitants. Downloaded data for Katowice and neighbourhood were intersected with all reclassified mean coherence images. Afterwards, the area statistic was calculated in the same method as was with mining areas. The bar chart is shown in the Figure 7.

In the chart it should be concluded, that urban areas characterises with the highest level of coherence. Also roads, railways and some agricultural areas can be easily monitored with InSAR technique. On the other hand, in forests and water bodies the areas of very low level of coherence preponderates (over 95\%). This is caused by the specification of radar signal's reflectance. In water bodies and areas covered with forests, almost whole signal is absorbed, reflected in the same angle as the incidence angle or scattered in random directions. However, in urban areas it is nearly totally backscattered to the sensor (https://nsidc.org/sites/nsidc.org/files/files/ SARTheory.pdf). Hence, if the signal cannot be registered in radar image, it is not possible to be calculated as high values in coherence maps.

The Stara Ligota I mining area is mostly covered by buildings and common industrial regions, thus the coherence is very high. In Sośnica III besides urban areas, there are numerous agricultural fields. Hence,

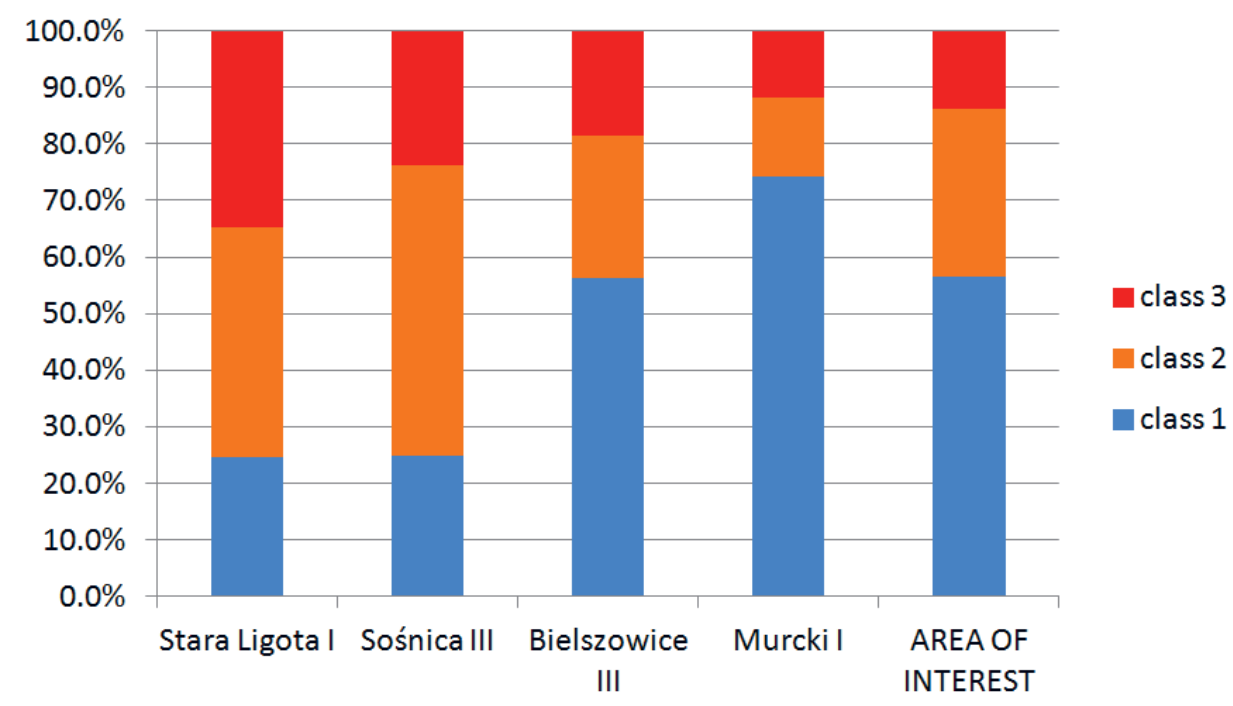

Fig. 6. The contribution of coherence classes in specific mining areas

Rys. 6. Procentowy udział klas koherencji w poszczególnych terenach górniczych 
big areas with class 2 is performed. In Murcki I mining area is covered primarily by forests which explains the lack of coherence in over $70 \%$ of this terrain. The transparent reclassified mean coherence images with orthophotomap from Polish Geoportal in the background are shown in Figure 8 and Figure 9.

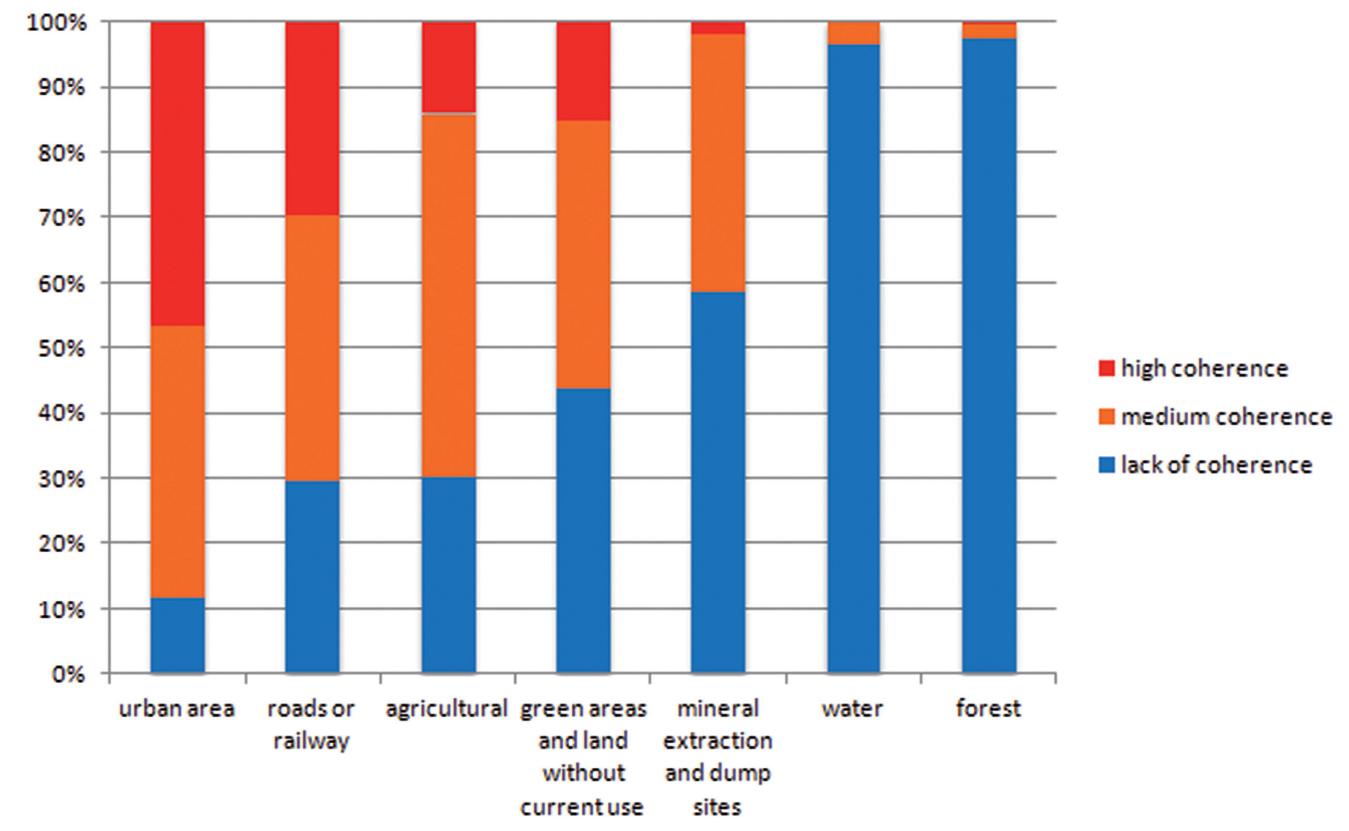

Fig. 7. The contribution of coherence classes in specific land use/land cover areas

Rys. 7. Udział klas koherencji w poszczególnych rodzajach pokrycia/użytkowania terenu

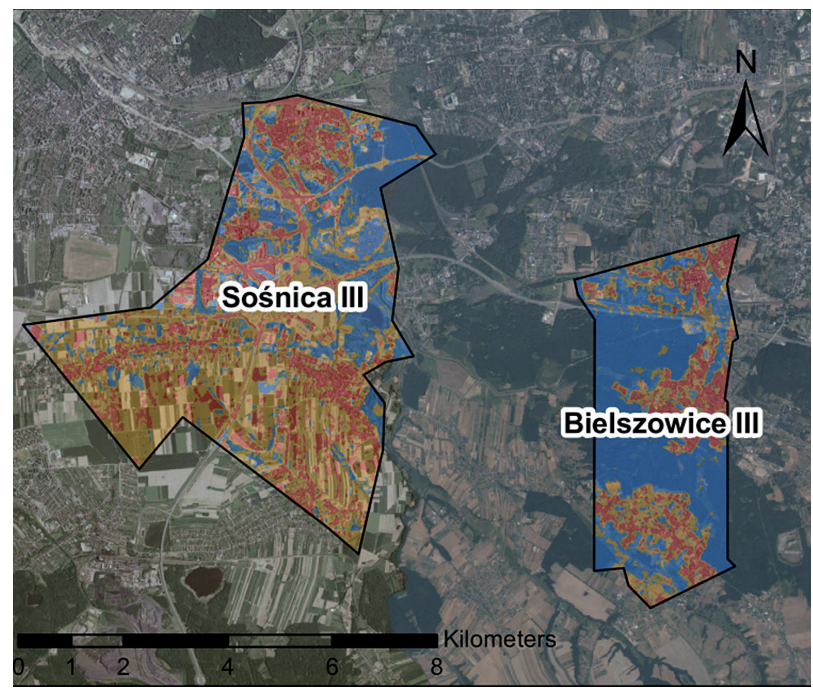

Fig. 8. Reclassified mean coherence map of Sośnica III and Bielszowice III mining areas with orthophotomap in the background

Rys. 8. Mapa zreklasyfikowanej uśrednionej koherencji dla terenów górniczych Sośnica III i Bielszowice III z ortofotomapą w tle

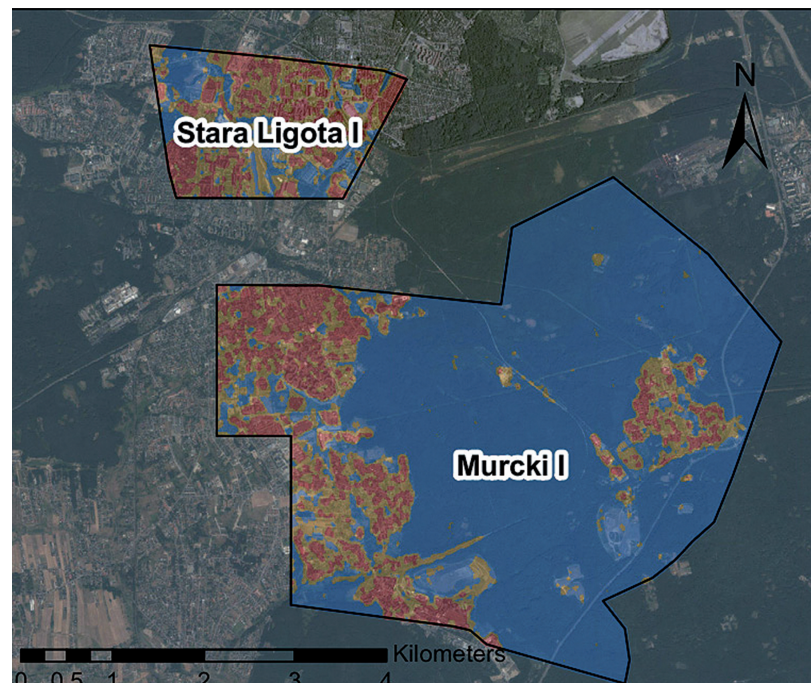

Fig. 9. Reclassified mean coherence map of Stara Ligota I and Murcki I mining areas with orthophotomap in the background

Rys. 9. Mapa zreklasyfikowanej uśrednionej koherencji dla terenów górniczych Stara Ligota I i Murcki I z ortofotomapą w tle 


\subsection{Generalization of coherence classes}

As a last step of this study, a generalization of obtained results was performed for Sośnica III mining area. This procedure was achieved in three parts. First of all, after converting raster into polygons, a minimal area which is found as still important was defined. In other words, a singular subsidence area is a big region. Thus, there is no need in presenting results with all small areas of each class, because such areas may cov- er only a slight part of a subsidence area. Hence, an area of 1 hectare (which approximately correspond with a shape of 10 by 10 pixels of interferogram) was defined as a minimal region, which may be significant. All smaller object were eliminated. Furthermore, obtained polygons were simplified and then smoothen in order to make them easy to visualize. In that way, a map with isolines of coherence classes was achieved, whereas each object is big enough to contain a significant fraction of singular subsidence area.
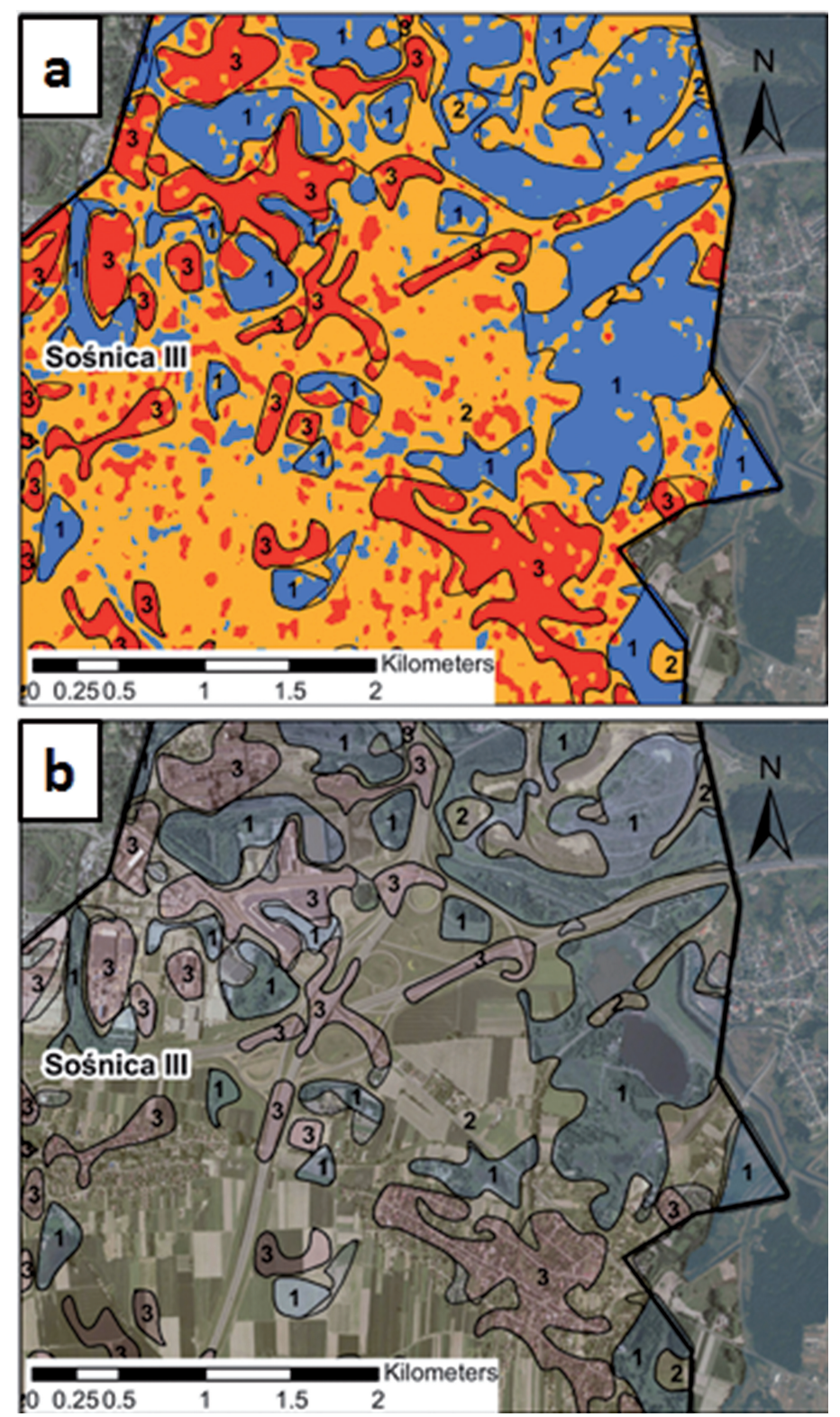

Fig. 10. Generalized isolines of coherence classes with original mean coherence map (a) and orthophotomap in the background (b) Rys. 10. Zgeneralizowane izolinie klas koherencji z mapą uśrednionej koherencji (a) oraz ortofotomapą w tle (b) 
The generalization process had an impact on a real contribution of coherence classes. Calculated values of area are shown in Table 6 .

Table 6. Results of generalized coherence classes' areas for Sośnica III mining area

Tabela 6. Wyniki zgeneralizowanych powierzchni klas koherencji dla terenu górniczego Sośnica III

\begin{tabular}{|c|c|c|c|}
\hline $\begin{array}{c}\text { Mining } \\
\text { area }\end{array}$ & $\begin{array}{c}\text { Low } \\
\text { coherence } \\
\text { (class 1) } \\
\text { [ha] }\end{array}$ & $\begin{array}{c}\text { Medium } \\
\text { coherence } \\
\text { (class 2) } \\
\text { [ha] }\end{array}$ & $\begin{array}{c}\text { High } \\
\text { coherence } \\
\text { (class 3) } \\
\text { [ha] }\end{array}$ \\
\hline Sośnica III & 757.0 & 1818.1 & 666.1 \\
\hline
\end{tabular}

After comparing these values with original classes, it can be deduced, that for class 1 compiled approximation error is the lowest (circa 6\%). Classes 2 and 3 are characterized with greater errors $(9 \%$ and $14 \%$, respectively). This is caused by a big amount of small areas with a sudden growth of the coherence, particularly in singular buildings neighbourhood. There is no point in mapping such small regions in monitoring subsidence areas.

\section{CONCLUSION}

In the presented study, it was shown a high potential of usage radar interferometry technique to perform efficient monitoring of some of the selected mining areas - Sośnica III and Stara Ligota I. A table with results in hectares is shown in Table 5. Analyzing Figure 10, not every area is good to interpret subsidence areas with InSAR technique. Significantly, in regions in neighbourhood with water bodies and also in forests, there is a need to study such areas with using survey lines.

The strong correlation between coherence value and land cover was proved. Acquiring the Sentinel-1 radar data with short temporal base and hence small temporal decorrelation allows to interpret interferograms with low level of noise in urban and also agricultural areas. However, in some studies (e.g. Groningen gas field), when the temporal decorrelation was high, mostly due to long temporal base with using ERS radar data, the PS (Permanent Scatterers) InSAR technique is used entirely successfully (Ketelaar G., 2008). Other studies have proved, that especially in areas, where vertical move- ments are slow (few cm per year), PS InSAR technique may be very efficient (Leśniak A., Porzycka S., 2007).

Satellite radar interferometry is one of remote sensing technique, which may bring huge economic and environmental benefits (Przeździcki K., Zawadzki J., 2016). The further works are focusing on creating the coherence maps with data from whole year, to overcome the influence of seasons and biomass distribution.

\section{ACKNOWLEDGEMENT}

Special thanks to European Space Agency for sharing Sentinel data and software for data processing, to Dean of Department of Mining Surveying and Environmental Engendering AGH for help with setting up hardware necessary for this project. I would also like to thank dr. A. Krawczyk for theoretical contribution and opinions in this study.

\section{BIBLIOGRAPHY}

Cabała J., Ćmiel S., Idziak A. "Environmental impact of mining activity in the Upper Silesian Coal Basin (Poland)", Geologica Belgica, volume 7, 2004, number 3-4 - Proceedings of the 5 th European Coal Conference.

Gonzalez R. C., Woods R. E. "Digital Image Processing”, Pearson, 2008, ISBN 9780133002324.

Hanssen R., Ferretti A., Grebenitcharsky R., Kleyer F., Elawar A., Bianchi M. "Atmospheric Phase Screen (APS) estimation and modeling for radar interferometry", In: Fourth International Workshop on ERS/Envisat SAR Interferometry, 'FRINGE05', Frascati, Italy, 28 Nov-2 Dec 2005.

Ketelaar G. "Monitoring surface deformation induced by hydrocarbon production using satellite radar interferometry", Doctor thesis, Delft Institute of Earth Observation and Space Systems, Delft University of Technology, 2008.

Krawczyk A., Perski Z., Hanssen R. "Application of ASAR interferometry for motorway deformation monitoring”, ESA ENVISAT Symposium, Montreux, Switzerland, pp. 23-27, 2007/4.

Leśniak A., Porzycka S. „Detekcja pionowych przemieszczeń terenu na obszarach górniczych z wykorzystaniem satelitarnej interferometrii radarowej typu PSInSAR", Archiwum Fotogrametrii, Kartografii i Teledetekcji, 2007 vol. 17b, p. 451-461, ISBN 978-83-920594-9-2.

Mirek K. "Interferometric synthetic aperture radar InSAR method for study and monitoring subsidence over mining areas", Polish Journal of Environmental Studies, No. 3A, 2009.

Perski Z. "Applicability of ERS-1 and ERS-2 InSAR for land subsidence monitoring in the Silesian coal mining region, Poland", International Archives of Photogrammetry and Remote Sensing, volume 32, pages: 555-558, 1998 
Perski Z. "Earth's surface deformation measurements with SAR interferometry. Methods and newest achievements", Geoinformatica Polonica, 2009, T. 9, pp. 79-92.

Perski Z., Popiołek E., Hejmanowski R., Krawczyk A. “The application of satellite radar interferometry to the examination of the areas of mining exploitation" SURFACE Mining braunkohle and other minerals, T. 54, pp. 74-82, 2002.

Przeździcki K., Zawadzki J. "Chosen remote-sensing methods in monitoring environment of mining areas", Systemy ws- pomagania w inżynierii produkcji, No. 1(13), pp. 11-24, September 2016.

Yin Q., Hong W., Lin Y., Li Y. "Soil moisture change estimation using InSAR coherence variations with preliminary laboratory measurements", Article in Science China, Information Sciences 60(2) · February 2017 DOI: 10.1007/s11432-0150839-1.

https://earth.esa.int

https://nsidc.org/sites/nsidc.org/files/files/SARTheory.pdf 